Working Paper No. 584, 2002

Minimum Wages and Employment in Swedish Hotels and Restaurants

by Per Skedinger

IUI, The Research Institute of Industrial Economics

P.O. Box 5501

SE-114 85 Stockholm

Sweden 


\title{
Minimum wages and employment in Swedish hotels and restaurants*
}

\author{
by \\ Per Skedinger** \\ November 11, 2002
}

\begin{abstract}
This paper considers the effects of union-bargained minimum wages on transitions into and out of employment in the hotels and catering industry over the period 1979-99. This industry is characterised by a high fraction of unskilled labour input, high worker turnover and binding minimum wages. The empirical approach identifies workers affected by real minimum wage increases and decreases, respectively. Job separations and accessions for the treatment groups are then contrasted to the outcomes for control groups, with wages marginally above those of the treatment groups. Unlike previous studies, this paper also considers same-period transitions for same-wage workers who are unaffected by minimum wage changes. This procedure should help to control for unobserved differences between high- and low-wage workers and is made possible by the diversified minimum wage structure of the industry. According to the results, increasing minimum wages tend to be associated with non-negligible employment effects (except for teenagers during 1993-98). The evidence regarding decreasing minimum wages is less conclusive.
\end{abstract}

Keywords: minimum wages, employment. JEL classification: J23, J31, J51.

\footnotetext{
" I would like to thank Bertil Holmlund, Erik Mellander and seminar participants at EALE'02 (Paris), FIEF, IFAU, IUI and SOFI for helpful comments and suggestions on earlier versions of the paper. Thanks are also due to the Hotel and Restaurant Employers' Association (SHR), especially Göran Granhed, and the Confederation of Swedish Enterprise, in particular Eva Dahlerus and Ari Hietasalo, for generously providing the data used in this study and for discussions. I am indebted to Anders Forsberg, the Hotel and Restaurant Workers' Union (HRF), and Per Ågren, the Association of Swedish Engineering Industries, for valuable information on wage formation and employment conditions in the hotels and restaurants industry. Jörgen Nilson and Magnus Wiberg provided able research assistance. Naturally, the author alone is responsible for the contents of the paper. Financial support from the Office of Labour Market Policy Evaluation (IFAU) and Marianne and Marcus Wallenbergs Stiftelse is gratefully acknowledged.

${ }^{* * *}$ Research Institute of Industrial Economics (IUI), Box 5501, SE-114 85 Stockholm, Sweden, e-mail: pers@iui.se.
} 


\section{Introduction}

The employment effects of minimum wages have been subject to extensive empirical scrutiny for decades. In recent work, two different approaches can be identified. The first one considers net worker flows and the overwhelming majority of the studies belong to this category. The second approach deals with gross worker flows. The influential studies by Card \& Krueger (1994, 1995), on U.S. fast-food restaurants, are examples of the net flows approach, as are the British studies by Dickens et al. (1999) and Machin \& Manning (1994), and Neumark \& Wascher (1992), on U.S. data, although the evaluation methodologies differ in other respects. None of these studies, except Neumark \& Wascher (1992), find strong negative employment effects from minimum wage increases, and some even suggest small positive effects. ${ }^{1}$

This paper follows a line of analysis used by Abowd et al. (2000a, 2000b), on U.S. and French data, Askildsen et al. (2000), for Norway, and the American studies by Currie \& Fallick (1996) and Zavodny (2000), in which gross worker flows are considered. Most of these studies find non-negligible negative employment effects from minimum wages. Askildsen et al. (2000) is, however, an exception. The gross flows approach, which requires longitudinal microdata on individuals, offers the advantage of allowing employment adjustment to minimum wages to be disaggregated into hirings and separations, rather than net changes in the total number of employed.

The gross flows approach identifies workers affected by real minimum wage increases and decreases, respectively. Job separations and accessions for the treatment groups are then contrasted to the outcomes for control groups, with wages marginally above those of the treatment groups. The validity of the method hinges, inter alia, on the assumption of comparability of treatment and control groups. Even in the absence of a minimum wage, the control group is likely to exhibit fewer separations and accessions. It is argued that a higher degree of comparability is achieved in this study than in previous analyses. This is due to the unusual quality and detail of the data set employed, covering workers in the hotels and catering industry. The rates within the chosen industry are differentiated by age, region, occupation and experience. A diversified

${ }^{1}$ Dolado et al. (1996) summarise findings regarding European labour markets. Edin \& Holmlund (1994), the only previous study on Swedish data, report negative employment effects for teenagers in manufacturing. 
structure is typical for labour markets with union-bargained minimum wages. Although differentiation of rates depending on region and age occur also in statutory systems, industry-, occupation- and experience-specific rates are less common (OECD, 1998). Unlike previous papers using the gross flows approach, this study makes use of the diversified structure in order to identify unaffected workers with the same wages as workers assumed to be affected by increasing or decreasing minimum wages. In addition, the unaffected workers are located in the same industry and have experienced minimum wage changes in the same direction as the affected workers. ${ }^{2}$ These unaffected workers have been subjected to a "pseudo-experiment", since they should not be expected to differ in transition probabilities from their respective control groups due to changing minimum wages. The information from the pseudo-experiments should help to control for unobserved differences between high- and low-wage workers and is used as an extra check on the validity of the results.

The hotels and catering industry appears to be a suitable candidate for investigating the employment effects of minimum wages. The fraction of unskilled labour input is high and the minimum wages, which apply to all workers and firms, tend to be binding. ${ }^{3}$ The availability of escape routes to alternative employment with lower minimum wages should be limited, although worker turnover rates are very high. Wage costs constitute 35-40 percent of total factor costs (SHR, 1996), which is more than in manufacturing or in retail services. A potential drawback with the choice of this industry, however, is the existence of underground activity. It is often alleged that employees in the restaurant business are more prone not to declare their earnings than workers in other sectors of the economy.

The data set contains over 200,000 observations on unskilled workers and covers the period 1979-99. It includes ample information on worker and firm characteristics - age, gender, hourly wage, occupation, job tenure, type of employment contract, region and firm size. The minimum wages have been collected from the collective wage agreements and added to the data set.

\footnotetext{
${ }^{2}$ In their respective pseudo-experiments based on homogeneous minimum wages, both Abowd et al. (2000b) and Zavodny (2000) consider workers who have experienced minimum wage changes of the opposite direction during other time periods.

${ }^{3}$ The assertion in Dolado et al. $(1996$, p.325) that "[i]n Sweden...nobody actually receives the minimum" is based on evidence from manufacturing (Östros, 1994) and is not necessarily correct for other industries, and certainly not for hotels and restaurants.
} 
This paper proceeds as follows. Section 2 sets out to describe the evolution of minimum wages in hotels and catering over the period of study. The data set is discussed in Section 3, which also describes the empirical strategy. In Section 4, the estimates of the binomial logit model are presented. A brief conclusion is given in Section 5.

\section{Minimum wages in hotels and cater- ing}

Unlike many other countries, e.g., the U.S. and France, there is no minimum wage legislation in Sweden. As in other Scandinavian countries, minimum wages are subject to bargaining between employers and unions and are part of collective agreements. The agreements apply to all firms in the industry, whether the workers are unionised or not. In general, the minimum wages are industry-specific and nationwide. In the hotels and restaurants industry, wages for manual workers are determined in collective agreements between the Hotel and Restaurant Workers' Union (HRF) and the Hotel and Restaurant Employers' Association (SHR).

In the collective agreements, contractual wage increases as well as minimum wage levels are negotiated for various worker categories. The contractual wage increases consist of general as well as local increases, defined in SEK per hour or month. General wage increases apply to all workers in a given job or occupational group in the whole industry, while local increases accrue to workers on an individual basis. A local "wage pot" (lönepott), the sum of which is pre-specified in the industry wage agreements, is distributed among the workers according to the outcome of local bargaining. On top of the contractual wage increases, there is also wage drift, i.e., locally negotiated wage increases. Traditionally, wage drift has assumed modest proportions in the hotels and catering industry, being almost entirely absent prior to the 1990's.

Like the contractual wage increases, minimum wages are not subject to local bargaining. During the period of study, 1979-99, some changes have occurred in the differentiation of the rates. In 1979, the minimum wages were defined for around 15 occupations and were also dependent on experience and region. In some occupations, minors (i.e., under the age of 18) were subject to lower minimum wage levels. The regional differentiation ceased in 1986, when the two former wage regions (Greater Stockholm and outside Greater Stock- 
holm) were merged into one. In 1993, minimum wages were defined for only two occupational categories, skilled and unskilled workers, retaining the dependence on experience. At the same time, lower minimum wage levels were introduced for all unskilled workers below the age of 20. Minimum wages for 18 -year-olds (19-year-olds) were defined to be 85 (95) percent of the minimum wage for unskilled workers at least 20 years of age.

In the collective wage agreements, jobs are defined as unskilled if previous training is not required and introductory training is provided at the workplace. Formal education, above primary school level (grundskola), is not required in order to perform the tasks. Hotel chambermaid, hotel assistant and restaurant assistant are examples of unskilled jobs. Skilled work is defined as jobs which require vocational training at the high-school level (gymnasium), equivalent formal education, or a long period of practical experience. Among the jobs defined as skilled are receptionist, night-porter, cook, cold-buffet manageress, chef and waiter/waitress.

Figure 1 shows the development of real hourly minimum wage in 1995 SEK (deflated by the consumer price index for hotels and restaurants ${ }^{4}$ ) for the four unskilled occupations in the hotels and catering industry which are included in the econometric analysis. In order to achieve comparability over time and across occupations, the minimum wages pertain to workers outside Greater Stockholm, at least 20 years old and with job tenure less than one year. It is seen that the minimum wages decreased sharply from 72-75 SEK per hour in 1979 to around 55 in 1984, fell further to around 52 in 1991 and have since risen somewhat to reach 60 in 1999. Even after the recent increase, the minimum is thus still substantially lower than in 1979. Minimum wages were initially somewhat higher for restaurant assistants (level I) than for the other groups, but the differential has diminished over time and from 1993 all unskilled workers have been subject to the same minimum.

Figure 2 presents the regional differentiation of minimum wages over time. For expositional convenience, the figure contains data for only one occupation, hotel chambermaids, but the same pattern applies to the other three occupations in the analysis. According to the figure, regional differentiation of minimum wages in Greater Stockholm vs. the rest of the country has been quite modest and has not been used at all after 1985 .

\footnotetext{
${ }^{4}$ The choice of this deflator is motivated in Section 3.
} 


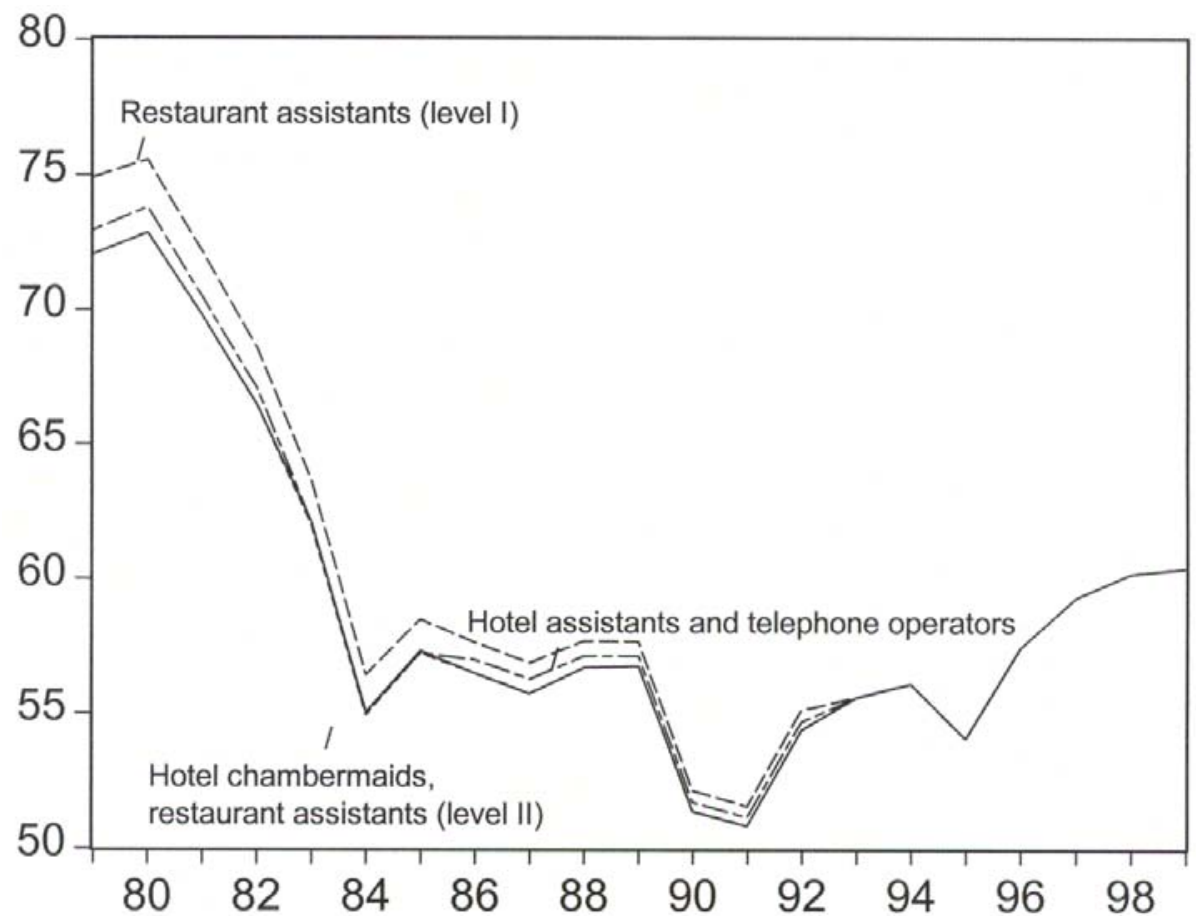

Figure 1. Real hourly minimum wages, by occupation, 1979-99. SEK.

Notes: The minimum wages are deflated by CPI (hotels and restaurants, 1995=1) and refer to workers at least 20 years old with job tenure less than one year. 


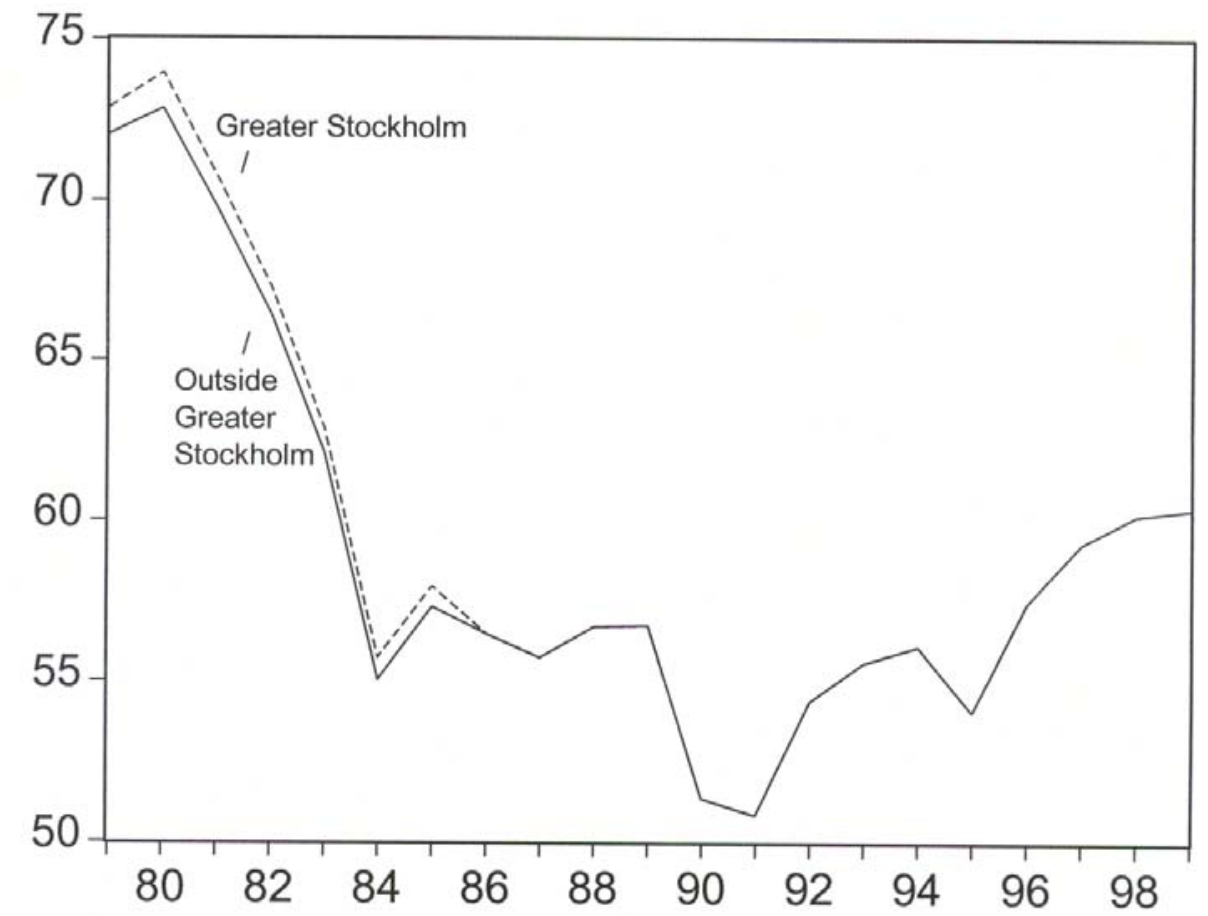

Figure 2. Real hourly minimum wages for hotel chambermaids, by region, 1979-99. SEK.

Notes: See notes to Figure 1. 


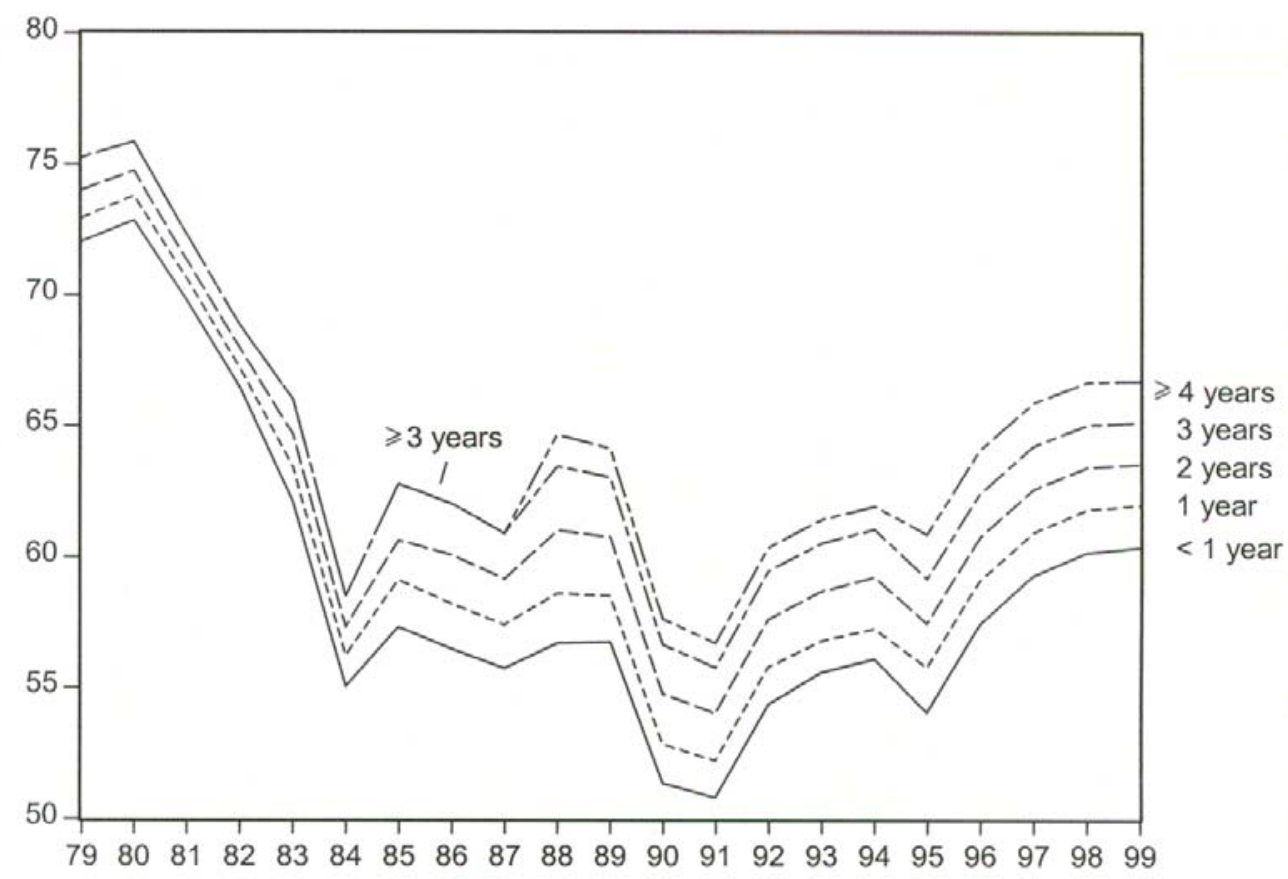

Figure 3. Real hourly minimum wages for hotel chambermaids, by job tenure, 197999. SEK.

Notes: The minimum wages are deflated by CPI (hotels and restaurants, 1995=1) and refer to workers at least 20 years old. 


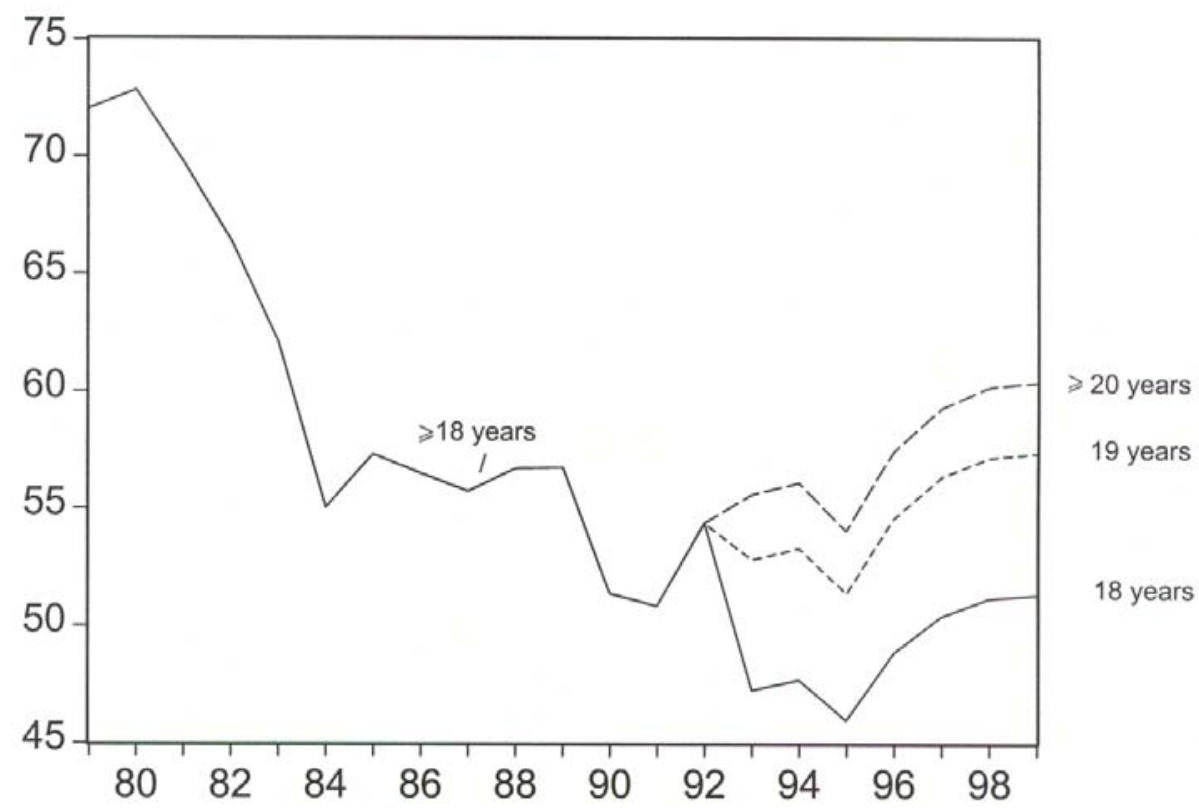

Figure 4. Real hourly minimum wages for hotel chambermaids, by age, 1979-99. SEK.

Notes: The minimum wages are deflated by CPI (hotels and restaurants, 1995=1). For the period 1979-92 and for workers at least 20 years old in 1993-99 the minimum wages refer to workers with job tenure less than one year. 


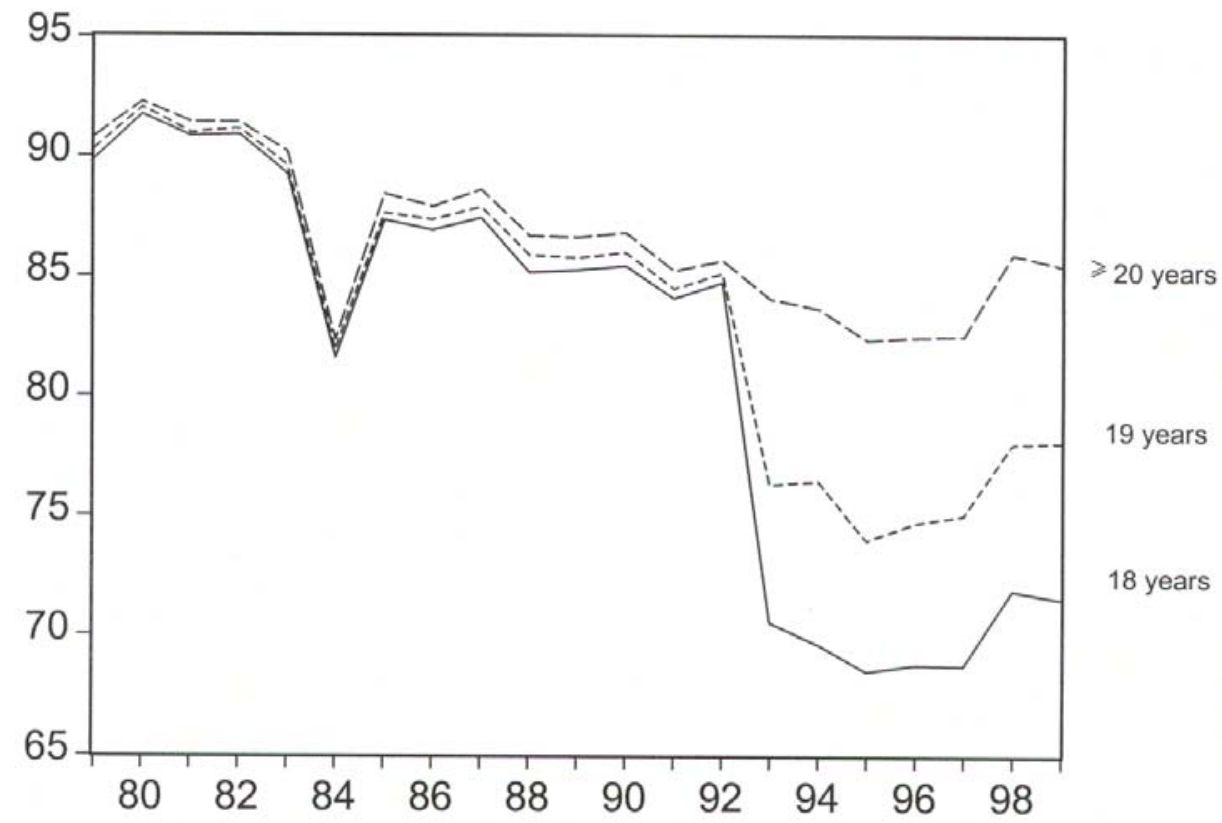

Figure 5. Minimum wage bite for unskilled workers, by age, 1979-99. Percent of wages for unskilled workers aged 36-45.

Notes: The minimum wages during the period 1979-92 are weighted averages of the minimum wages for hotel chambermaids, hotel assistants and telephone operators, and restaurant assistants. 
In Figure 3, the differentiation of minimum wages by job tenure is displayed. Different minimum wages have applied to workers with job tenure less than one year, one year, two years, at least three years, and, from 1987, at least four years. While these differentials were small until the mid-1980's, they have since widened. For example, in 1981 a hotel chambermaid with four years' experience was subject to a 3.6 percent higher minimum wage than a chambermaid with no experience and in 1999 this difference had increased to 10.5 percent.

Figure 4 shows how minimum wages have been differentiated by age. Minors, i.e., workers below the age of 18 , are not considered, since minimum wages for these workers are not included in the econometric analysis. Until 1992, the same minimum wage applied to all hotel chambermaids above the age of 18, with job tenure less than one year. From 1993, different minimum wages have applied for 18-year-olds, 19-year-olds and workers at least 20 years old. In 1993, 18-year-old workers experienced a large decline in the real minimum, which dropped from 55 to 47 SEK, but subsequently rose somewhat to 51 in 1999. This development stands in contrast to the pattern for older workers, whose minimum wages increased over the period 1993-99.

According to Figure 5, the minimum wage bite, i.e., the ratio of minimum wages to average wages (for 36-45-year-olds), has declined over time. In the beginning of the period of study, the bite was over 90 percent. It has since diminished somewhat for 20-year-old workers and even more for teenagers after 1992, to between 72 and 78 percent of average wages for older workers. The dip in 1984 is explained by the fact that during this year nominal minimum wages remained unchanged.

\section{The data set}

The data set, obtained from the Confederation of Swedish Enterprise (Svenskt Näringsliv, formerly SAF), contains information on firms and manual workers in hotels and restaurants over the period 1979-99. The annual observations refer to September each year. Most seasonal workers, who tend to be employed during the summer or winter months, are thus not included in the data. Coverage is limited to firms that are members of SHR, but the data should be representative of the business as a whole. The member firms account for about 75 percent of turnover in the industry. The various establishments include hotels, 
restaurants, staff dining rooms, hotel restaurants and other eating-places of many kinds. All member firms were surveyed during the period 1979-91, while cut-offs were applied after 1991 (10 employees in 1992-93, 5 employees from 1994 to 1999). Each year there is also a small number of the surveyed firms which, for some reason, do not report to the Confederation. Among the firms which do report, it is, according to the Confederation, safe to assume that all employees are included. ${ }^{5}$

As should be expected in data sets like this, there is attrition, both of workers and of firms. The data set contains unique identifiers for workers and firms. It is possible to identify in which year an individual worker is separated from a firm, but it is not known whether the separation is voluntary (quit) or involuntary (layoff). Workers also enter the data set as new hires. Firm attrition, also identifiable on a year-to-year basis, is due to one of two causes: i) the firm has gone out of business; or ii) the firm is still in business, but is not reported (due to, e.g., being below the cut-off point, applicable during 1992-99). If the firm has changed ownership or merged with another firm, the firm identifier may also change. In such a case, a firm will erroneously be identified as a new entrant in year $t$, while it actually has been present in the data set in $t-1$ under the old identifier. The same firm will of course, also erroneously, be identified as exiting the data set in $t$.

The data set contains information on wages, hours, age, gender, region, occupation, type of employment contract, job tenure and firm size (number of employees). The wage measure used is the hourly wage, calculated as wages divided by work hours. (For the period 1998-99, a direct measure of the hourly wage is used, since it is available in the data.) Since the wage measure excludes overtime pay, bonuses and fringe benefits, it corresponds to the measure in the minimum wage agreements. The wage is deflated by the consumer price index in the hotels and catering industry. ${ }^{6}$ The chosen wage measure is intended to represent real production wages in hotels and restaurants, which rests on the assumption that consumer prices proxy output prices reasonably well in the absence of imports and the production of intermediate goods.

The type of contract indicates whether a worker is employed on a permanent contract (tillsvidareanställd) or not. Employment protection legislation was

\footnotetext{
${ }^{5}$ Underground workers, however, may or may not be included in the data.

${ }^{6}$ The consumer price index includes value added tax. The preferred deflator is the producer price index, but this is not available for the later years of the period of analysis.
} 
liberalised in 1982, in order to facilitate exceptions to permanent contracts and allow a probationary period of six months. Further steps towards liberalisation were taken in 1994, when the probationary period was extended to twelve months. In 1995, the probationary period was restored to its previous length of six months. Traditionally, the incidence of fixed-term contracts has been relatively high in the hotels and catering business as compared to other industries. This should facilitate firms' adjustment of employment to changes in minimum wages.

Job tenure is measured in years, with an upper limit of at least three or four years. Working at least 75 per cent of full-time (i.e., 30 hours per week), or 1,300 hours over a longer period, is sufficient to qualify for an additional year of job tenure. A complication with the measure of job tenure in the data is that it does not necessarily reflect actual job tenure. It is sometimes practice among employers to award an extra year or two of job tenure as a bonus to employees who are regarded as particularly valuable to the firm. Increases in job tenure carries with them higher minimum wages, as noted in Section 2, and are transferable to other employers.

Information on minimum wages was collected from the collective agreements ${ }^{7}$ and added to the data set. The minimum wage applicable to the month of September was assigned to each worker and year, based on his or her occupation (1979-92) or occupational group (1993-99), job tenure, region (197985) and age (1993-99). Nominal minimum wages have increased every year except 1984, the adjustments occurring at varying times of the year, sometimes close to the month of September. Workers on a fixed-term contract were assumed to have job tenure $<1$ year and assigned the corresponding minimum wage.

As mentioned previously, the analysis is limited to unskilled workers - hotel chambermaids, hotel assistants and telephone operators, and restaurant assistants. Minimum wages tend to be less binding for skilled workers and the structure of minimum wages for that group does not lend itself easily to the econometric analysis performed in this paper. The group of restaurant assistants is divided in two occupations defined by different skill levels, level I (restaurangassistent) and level II (restaurangbiträde), with lower required skills. Furthermore, groups for which minimum wages or wages could not easily be de-

\footnotetext{
${ }^{7}$ Kollektivavtal mellan Sveriges Hotell- och Restaurangföretagare, Aktiebolaget Trafikrestauranger och Hotell- och Restauranganställdas förbund, various issues.
} 
fined have been excluded, i.e., minors and multiple job holders. ${ }^{8}$ In addition, some observations susceptible to measurement errors, i.e., outliers, were excluded: (i) wages below 75 percent of the minimum wage; (ii) wages above the average wage (by occupation and job tenure) multiplied by three. After these exclusions, the sample size is about 207,000 observations.

The existence of underground activity may introduce measurement errors in the turnover data. Such work tends to take two forms; either the worker is recorded as being employed at the minimum wage, while he or she is also receiving extra pay on the side, or the worker is not in the records at all. The former practice seems to be the less prevalent of the two and is usually confined to the hiring of certain skilled and sought-after workers. While the latter practice is not uncommon in general, it seems to be extremely rare in large firms, e.g., restaurant or hotel chains, which may be due to higher reputation costs. The minimum wage data are probably more reliable, but it should be noted that misclassifications of occupation will generate measurement errors in the minimum wage variable.

\subsection{The sample partition, econometric specification and sample statistics}

For the purposes of analysing the employment effects of changing minimum wages, the sample is divided into two parts: observations with increasing real minimum wages and observations with decreasing real minimum wages. Following the gross flows method of Abowd et al. (2000a, 2000b), the observations in each of the two categories are then sliced into another four groups, depending on the worker's position in the wage distribution.

The motivation behind this exercise is to identify workers who are affected by increases and decreases in minimum wages (the treatment group) and workers who qualify as a suitable comparison, assumed to be unaffected by changes in the minima (the control group). For the time being, it is assumed that there is only one minimum wage.

\footnotetext{
${ }^{8}$ For minors, below 18 years of age, minimum wages could not be defined for the period 197992 , since they vary with months of job tenure, which are not observed, and are subject to exemption rules for some occupations. Although minimum wages for minors could be defined for the period 1993-99, the data contain too few observations on these workers to make an analysis meaningful.
} 
The following groups are defined for an increasing real minimum wage, i.e.,

$$
w_{t}^{\min }<w_{t+1}^{\min } .
$$

Below: $\quad w_{i, t}<w_{t}^{\text {min }}$

Treatment: $\quad w_{t}^{\min } \leq w_{i, t}<w_{t+1}^{\min }$

Control: $\quad w_{t+1}^{\min } \leq w_{i, t}<w_{t+1}^{\min } \times 1.05$

High: $\quad w_{i, t} \geq w_{t+1}^{\min } \times 1.05$,

where $w$ is the real wage, $w^{\min }$ is the real minimum wage and the subscripts $i$ and $t$ indicate the individual worker and year, respectively. The "below" group refers to workers with sub-minimum wages in year $t$. Workers with wages between the two minimum wages is defined as belonging to the "treatment" $(T)$, or affected, group, while those with wages just above the minimum wage in year $t+1$, i.e., up to five percent more, are part of the "control" $(C)$. The five percent interval is smaller than the one used in previous applications and is made possible by the presence of many observations within this range. Workers with wages above those of the control belong to the "high" group. According to competitive labour market theory, workers with current wages below the future minimum wage will be separated from the job, assuming that marginal productivity is constant over time and that workers are paid according to their (marginal) productivities. The hypothesis is thus that job separations are more frequent in the treated group, with lower wages, than in the control, with higher wages.

Applying the same logic, the following four groups are defined for a decreasing real minimum wage, i.e.,

$$
w_{t}^{\min }<w_{t-1}^{\min } .
$$




$$
\begin{array}{ll}
\text { Below: } & w_{i, t}<w_{t}^{\min } \\
\text { Treatment: } & w_{t}^{\min } \leq w_{i, t}<w_{t-1}^{\min } \\
\text { Control: } & w_{t-1}^{\min } \leq w_{i, t}<w_{t-1}^{\min } \times 1.05 \\
\text { High: } & w_{i, t} \geq w_{t-1}^{\min } \times 1.05 .
\end{array}
$$

With a decreasing minimum, the idea is that the affected workers will be more likely to be newly recruited, since in the previous period they fell below the minimum wage threshold. Thus the hypothesis is that job accessions are more frequent in the affected group than in the control. Once again, outcomes are compared for a group with lower wages $(T)$ to a group with higher pay $(C)$.

The theoretical framework above implicitly interprets separations as layoffs; a wage exceeding marginal productivity results in redundancies. It is, however, not unlikely that the majority of separations are quits. ${ }^{9}$ Unfortunately, it is not possible to distinguish between layoffs and quits in the data. A minimum wage increase may not only increase layoffs but also reduce quits. Our data on separations should capture the net effect.

The fact that many separations are quits raises the question which wage measure one should adopt. To begin with, the product wage will be used, as described above. ${ }^{10}$ This measure is relevant to the extent that separations are layoffs and possibly for hirings. (The distinction between layoffs and quits is probably not meaningful for workers on fixed-term contracts.) Later on, some experiments will be carried out with other wage measures, e.g., with the general CPI as deflator. This wage measure should be more relevant with respect to quits. Different wage measures not only imply different magnitudes and (possibly) directions of the minimum wage changes, but also different sizes of the treatment and control groups.

For workers within each group $k$ (below, treatment, control and high) with increasing minimum wages, the interacted variables

\footnotetext{
${ }^{9}$ According to Statistics Sweden, quits accounted for 90 percent of all separations in mining and manufacturing during the 1980 's. Few workers seem to be affected by minimum wage changes in this industry, however (cf. footnote 3 ).

${ }^{10}$ Robustness tests will be performed with payroll taxes included in the product wage measure.
} 


$$
I_{k} x\left[\log w_{t+1}^{\min }-\log w_{t}^{\min }\right]
$$

are defined, where $I$ is a dummy that takes on the value of 1 if the worker belongs to group $k=1,2,3,4$ and zero otherwise. The expression within brackets is the increase in minimum wages in percent, which is the same for all $k$. Similarly, for workers with decreasing minimum wages, we have

$$
D_{k} x\left[\log w_{t}^{\min }-\log w_{t-1}^{\min }\right],
$$

where $D$ is a dummy assuming the value of 1 if the worker belongs to the group $k$ and zero otherwise and the expression within brackets is the increase in minimum wages in percent, which is always a negative number. With more than one minimum, (1), (2) and the above decompositions are applied to each group for whom the different minimum wages are applicable.

Table 1. Assigned minimum wages in $t-1$ and $t+1$ for various job tenure

\begin{tabular}{|c|c|c|}
\hline Job tenure group $t$ & $\begin{array}{l}\text { Minimum wage } t-1 \text {, } \\
\text { by job tenure group }\end{array}$ & $\begin{array}{l}\text { Minimum wage } t+1 \text {, } \\
\text { by job tenure group }\end{array}$ \\
\hline$<1$ year & $<1$ year & 1 year \\
\hline 1 year & $<1$ year & 2 years \\
\hline 2 years & 1 year & 3 years \\
\hline 3 years $^{\mathrm{b}}$ & 2 years & $\geq 4$ years \\
\hline$\geq 3$ years $^{\mathrm{a}}$ & n.a. & $\geq 3$ years \\
\hline$\geq 4$ years $^{b}$ & n.a. & $\geq 4$ years \\
\hline
\end{tabular}
groups.

Notes: ${ }^{a}$ applicable $1979-86 ;{ }^{b}$ applicable $1987-$.

The specification of backward- and forward-looking minimum wages will have to take into account that minimum wages are dependent on job tenure and age. Minimum wages increasing in job tenure and age seems reasonable to the extent that marginal productivity also increases over time. ${ }^{11}$ Table 1 shows how minimum wages have been assigned to each job tenure group in periods $t-1$ and

\footnotetext{
${ }^{11}$ An implicit assumption in the previous literature is that marginal productivity is constant over time.
} 
$t+1$. It can be noted that different minimum wages are considered depending on whether the minimum increases (forward-looking, third column) or decreases (backward-looking, second column). Furthermore, minimum wages cannot be defined for the group with highest job tenure when the minimum decreases, since the job tenure group applicable in $t-1$ is unknown. It is assumed in Table 1 that work is full-time, which is a sufficient requirement for receiving an additional year of job tenure, and that no extra years are awarded by the employer.

In the regression models with increasing minimum wages, the worker either is separated from the job in the next period $(Y=1)$ or is not $(Y=0)$. With decreasing minimum wages, the worker either has accessed the job in the current period $(Y=1)$ or has not $(Y=0)$. The estimations are implemented through the binomial logit

$$
\operatorname{Prob}(Y=1)=\frac{e^{\beta^{\prime} x}}{1+e^{\beta^{\prime} x}}=\Lambda\left(\beta^{\prime} x\right)
$$

where 4 (.) indicates the logistic cumulative distribution function (see, e.g., Greene, 1993).

Among the explanatory variables in $x$ are included, as in most of the related literature, dummies for the previously defined groups in the wage distribution multiplied by the real increase (or decrease) in minimum wages, the real hourly wage, age, age squared, the number of employees in the firm and its square, and dummies for gender, job tenure group, occupation, permanent contract, year and region. The inclusion of the actual wage is intended to control for differing transition probabilities depending on the worker's position in the wage distribution.

Separate estimations are performed for the two periods 1979-92 and 199399. There are two reasons for this: (i) the data for the latter period do not contain variables for occupation (only a skilled/unskilled indicator) and permanent contract; and (ii) a break is created in the time series, since it is not possible to identify the occupation-specific minimum wages in 1992 for workers in 1993, with unknown occupation. (Note that minimum wages in some cases decrease in 1993, so the minimum in $t-1$ should be considered for these workers.)

Table 2 presents descriptive statistics for the sample with increasing minimum wages over the period 1979-91. The sample is divided into the below, treatment, control and high groups. Out of the 83,302 observations, 21,585 (26 percent) belong to the treatment group, according to the upper panel. The con- 
trol group contains almost as many observations $(19,874)$. Around one tenth of the observations have wages below the minimum wage. ${ }^{12}$

Table 2. Descriptive statistics. Sample of workers with increasing minimum wages, 1979-91. Grouping conditional on location in wage distribution.

\section{a. Variable means.}

\begin{tabular}{lllll}
\hline Variable & Below & Treatment & Control & High \\
\hline Not employed in the next period & 0.703 & 0.683 & 0.634 & 0.590 \\
Real increase in minimum wage & 0.032 & 0.050 & 0.042 & 0.037 \\
Real hourly wage, SEK & 57.33 & 58.35 & 61.67 & 68.47 \\
Age & 25.6 & 26.2 & 29.1 & 31.7 \\
Permanent contract & 0.709 & 0.720 & 0.641 & 0.582 \\
No. employees & 869 & 888 & 1,298 & 1,666 \\
Male & 0.286 & 0.266 & 0.242 & 0.241 \\
Occupation: & & & & \\
$\quad$ Hotel assistant, telephone operator & 0.019 & 0.021 & 0.023 & 0.017 \\
Hotel chambermaid & 0.156 & 0.162 & 0.222 & 0.296 \\
Restaurant assistant (level I) & 0.030 & 0.030 & 0.043 & 0.079 \\
$\quad$ Restaurant assistant (level II) & 0.795 & 0.787 & 0.712 & 0.609 \\
Job tenure: & & & & \\
$\quad<1$ year & 0.575 & 0.582 & 0.556 & 0.635 \\
$\quad$ 1 year & 0.111 & 0.111 & 0.094 & 0.074 \\
$\quad$ 2 years & 0.104 & 0.109 & 0.090 & 0.066 \\
$\geq 3$ years & 0.210 & 0.197 & 0.259 & 0.224 \\
$\quad$ No. obs. & 8,902 & 21,585 & 19,874 & 32,941 \\
\hline
\end{tabular}

\footnotetext{
${ }^{12}$ Observations below the minimum wage are commonplace in the empirical literature. One explanation for such observations (besides measurement errors and exemptions) put forward in conversations with union officials, is that the employer has not (yet) adjusted wage levels to the most recent collective wage agreement. If non-compliance is detected by the union, the worker gets compensation retroactively and the employer may be fined.
} 
b (cont.). Share of observations in wage distribution groups, by age and job tenure groups. Percent.

\begin{tabular}{lrlccc}
\hline Variable & No. obs. & Below & Treatment & Control & High \\
\hline Age: & & & & & \\
$18-25$ & 47,199 & 0.134 & 0.311 & 0.241 & 0.314 \\
$26-35$ & 15,397 & 0.080 & 0.215 & 0.233 & 0.472 \\
$36-45$ & 9,595 & 0.069 & 0.178 & 0.230 & 0.522 \\
$46-55$ & 6,787 & 0.061 & 0.172 & 0.233 & 0.533 \\
56-65 & 4,324 & 0.063 & 0.165 & 0.261 & 0.511 \\
Job tenure: & & & & & \\
$<$ 1 year & 49,632 & 0.103 & 0.253 & 0.223 & 0.421 \\
1 year & 7,718 & 0.128 & 0.311 & 0.243 & 0.318 \\
2 years & 7,316 & 0.123 & 0.327 & 0.248 & 0.303 \\
$\geq 3$ years & 18,636 & 0.100 & 0.228 & 0.276 & 0.396 \\
\hline
\end{tabular}

It can be noted that job separations are very frequent in all segments of the wage distribution, but declines with the wage. In the treatment group as many as 68 percent of the observations are not part of the sample in the next year. On average, real minimum wage increases have been 5 percent in the affected group and 4.2 percent in the control. Workers tend to be young and females are overrepresented; the average age is less than 30 except in the group with highest wages and only a quarter of the workers are male. The average firm size is surprisingly high and is due to the presence of a few very large firms in the data set, with over 1,000 employees each. There are many firms with only a few employees. Furthermore, it is seen that almost 60 percent of the observations in the treatment group have job tenure less than one year, but also that as many as roughly 20 percent have at least three years' experience in the job.

The lower panel of Table 2 provides more detailed information on the location of different worker groups in the wage distribution. Although the tendency to belong to the treatment group declines with age, a substantial share of the older workers is affected by increasing minimum wages. As regards job tenure, the share of affected workers does not decrease at all with increasing tenure. The treatment groups are apparently not confined to young workers with low job tenure, which possibly is a consequence of the fact that the minimum wage structure is diversified.

Sample statistics for observations with decreasing minimum wages during 1981-91 are reported in Table 3. The pattern displayed in Table 2 is largely re- 
peated, but it should be kept in mind that the observations with job tenure of at least three or at least four years have been excluded (see Table 1). Not surprisingly, then, e.g., job accessions are more frequent than the job separations in Table 2. Out of 56,254 observations, 20,888 (37 percent) are part of the treatment group. On average, real minimum wage increases have been -7.1 percent in the affected group and -5.6 percent in the control.

Table 3. Descriptive statistics. Sample of workers with decreasing minimum wages, 1981-91. Grouping conditional on location in wage distribution.

\section{a. Variable means.}

\begin{tabular}{lllll}
\hline Variable & Below & Treatment & Control & High \\
\hline Not employed in the previous period & 0.795 & 0.754 & 0.687 & 0.639 \\
Real increase in minimum wage & -0.048 & -0.071 & -0.056 & -0.041 \\
Real hourly wage, SEK & 59.05 & 60.80 & 61.32 & 67.53 \\
Age & 23.4 & 25.3 & 26.7 & 29.4 \\
Permanent contract & 0.551 & 0.545 & 0.489 & 0.425 \\
No. employees & 1,020 & 1,177 & 1,457 & 1,555 \\
Male & 0.303 & 0.289 & 0.286 & 0.266 \\
Occupation: & & & & \\
$\quad$ Hotel assistant, telephone operator & 0.021 & 0.026 & 0.021 & 0.017 \\
Hotel chambermaid & 0.145 & 0.166 & 0.221 & 0.304 \\
Restaurant assistant (level I) & 0.033 & 0.027 & 0.034 & 0.073 \\
$\quad$ Restaurant assistant (level II) & 0.801 & 0.782 & 0.723 & 0.606 \\
Job tenure: & & & & \\
$\quad<1$ year & 0.813 & 0.785 & 0.831 & 0.864 \\
$\quad$ 1 year & 0.081 & 0.086 & 0.069 & 0.055 \\
$\quad$ 2 years & 0.080 & 0.081 & 0.068 & 0.055 \\
3 years & 0.026 & 0.049 & 0.031 & 0.027 \\
No. obs. & 6,525 & 20,888 & 10,935 & 17,906 \\
\hline
\end{tabular}


b (cont.). Share of observations in wage distribution groups, by age and job tenure groups. Percent.

\begin{tabular}{lrlccc}
\hline Variable & No. obs. & Below & Treatment & Control & High \\
\hline Age: & & & & & \\
$18-25$ & 36,221 & 0.140 & 0.404 & 0.195 & 0.260 \\
$26-35$ & 10,088 & 0.086 & 0.332 & 0.190 & 0.392 \\
$36-45$ & 5,244 & 0.064 & 0.295 & 0.192 & 0.449 \\
$46-55$ & 3,059 & 0.047 & 0.289 & 0.199 & 0.465 \\
56-65 & 1,642 & 0.057 & 0.281 & 0.196 & 0.465 \\
Job tenure: & & & & & \\
$<1$ year & 46,246 & 0.115 & 0.354 & 0.197 & 0.334 \\
1 year & 4,070 & 0.130 & 0.442 & 0.186 & 0.243 \\
2 years & 3,935 & 0.133 & 0.428 & 0.190 & 0.249 \\
3 years & 2,003 & 0.085 & 0.508 & 0.170 & 0.237 \\
\hline
\end{tabular}

Table 4. Descriptive statistics. Sample of workers with increasing minimum wages, 1993-98. Grouping conditional on location in wage distribution.

a. Variable means.

\begin{tabular}{lllll}
\hline Variable & Below & Treatment & Control & High \\
\hline Not employed in the next period & 0.606 & 0.651 & 0.603 & 0.533 \\
Real increase in minimum wage & 0.045 & 0.073 & 0.040 & 0.038 \\
Real hourly wage, SEK & 57.66 & 58.24 & 63.36 & 73.37 \\
Age & 26.7 & 24.1 & 28.3 & 32.1 \\
No. employees & 243 & 330 & 355 & 352 \\
Male & 0.300 & 0.293 & 0.279 & 0.293 \\
Job tenure ${ }^{\text {a }}$ & & & & \\
$\quad<1$ year & 0.207 & 0.422 & 0.272 & 0.212 \\
$\quad$ 1 year & 0.151 & 0.205 & 0.167 & 0.119 \\
$\quad$ 2 years & 0.146 & 0.128 & 0.122 & 0.086 \\
$\quad 3$ years & 0.495 & 0.244 & 0.439 & 0.582 \\
$\quad$ & & & & \\
No. obs. & 4,508 & 18,941 & 16,063 & 28,689 \\
\hline
\end{tabular}


b (cont.). Share of observations in wage distribution groups, by age and job tenure groups. Percent.

\begin{tabular}{lrlccc}
\hline Variable & No. obs. & Below & Treatment & Control & High \\
\hline Age: & & & & & \\
$18-25$ & 37,754 & 0.077 & 0.384 & 0.242 & 0.297 \\
$26-35$ & 15,562 & 0.055 & 0.175 & 0.232 & 0.538 \\
$36-45$ & 7,345 & 0.051 & 0.139 & 0.243 & 0.568 \\
$46-55$ & 5,049 & 0.047 & 0.104 & 0.214 & 0.635 \\
$56-65$ & 2,491 & 0.051 & 0.078 & 0.183 & 0.688 \\
Job tenure & & & & & \\
$<1$ year & 15,650 & 0.049 & 0.350 & 0.250 & 0.350 \\
1 year & 8,708 & 0.065 & 0.306 & 0.275 & 0.355 \\
2 years & 6,186 & 0.088 & 0.270 & 0.283 & 0.360 \\
$\geq 3$ years & 26,371 & 0.070 & 0.120 & 0.239 & 0.571 \\
\hline
\end{tabular}

Notes: ${ }^{\text {a }}$ observations with workers aged $20-65$.

The estimations for the post-1992 period will be limited to the sample with increasing minimum wages, since there are few observations with a decreasing minimum (which for individuals over the age of 19 only occurs in one year, 1995). Table 4 presents descriptive statistics for the observations with increasing minimum wages.

The validity of the gross flows approach outlined above rests on the following assumptions:

\section{(i) Treatment is exogenous}

If decisions on hirings and separations are taken simultaneously with decisions on minimum wages, it will not be possible to separate the influence of the minimum on turnover. As in Askildsen et al. (2000), it is argued that the minimum wages, albeit being bargained over, are exogenous to the firm. This does not seem unreasonable since the minimum wages are determined nationally and do not vary according to local conditions (except for the modest regional differentiation up to 1985). As evident from Table 1, the estimation strategy is to assume that workers qualify for another year of job tenure (and a higher nominal minimum wage) the next year. Adopting an alternative strategy, e.g., making the job tenure group in $t+1$ dependent on actual work hours in $t$, would en- 
tail a minimum wage endogenous to the worker (with job tenure at least one year) or the firm.

(ii) The treatment and the control groups are as similar as possible, except for the treatment

If the treatment and control groups differ in important respects, the estimations may suffer from omitted variable bias. Even in the absence of a minimum wage, the control group is likely to exhibit more stable employment. Due to the richness of our data set, it is argued that greater comparability is achieved than in previous studies. Firstly, the data set allows the use of groups within unskilled occupations in the same industry, rather than larger sectors of the labour market. In contrast to previous studies, however, variables for education are missing. This is probably not a major problem, since the analysis is limited to occupational groups that are fairly homogeneous regarding educational attainment. Secondly, the wage segment of the control group is defined more narrowly than in other studies, due to the availability of many observations close to the minimum wage. Thirdly, as mentioned previously the diversified minimum wage structure makes it possible to use additional information on samewage workers who are unaffected by changes in the minimum wage. Arguably, this should help to control for a great deal of unobserved differences between high- and low-wage workers.

Any remaining unobserved individual heterogeneity may of course bias the results, to the extent that it is correlated with variables indicating whether a worker is subject to treatment or not. Due to selection and high turnover, few individuals are observed over two consecutive periods. This renders standard fixed-effects estimation in order to control for unobserved individual heterogeneity intractable in our context. ${ }^{13}$ Firm heterogeneity is another matter as firms do not necessarily drop out of the sample, so it should be possible to control for this source of bias.

\footnotetext{
${ }^{13}$ In models with discrete dependent variables, maximum-likelihood estimation of fixed effects produces inconsistent estimates (Baltagi, 1995). Conditional likelihood estimation, which uses observations where the individuals change state $(Y)$, yields consistency but is very restrictive in our case. Only individuals observed over at least two periods, accounting for around 10 percent of all observations, can be used.
} 
(iii) The control group is not affected by the treatment

Workers above the minimum wage may also be influenced by changes in the minimum. Although the control group is not directly affected, there may be an indirect spillover effect operating through the going wage. With increasing minimum wages, say, firms may wish to substitute workers with higher marginal productivity for lower-productivity workers, thereby increasing demand and wages for the former group. There may also be a ripple effect if high-wage workers increase their wage claims, in order to restore wage differentials. To the extent that substitution and ripple effects are picked up by the variables (1) and (2) for the control group, a possible interpretation of the difference $T-C$ is a treatment effect including such spillover. It seems reasonable to assume that there is more spillover if the wage interval for the control group is narrow, in which case there is a trade-off against achieving more comparability in other worker characteristics across treatment and control groups.

\section{Econometric results}

Separate estimations will be performed for the samples with increasing and decreasing minimum wages and for different time periods. In addition, regressions will be run on the full sample (as described in Tables 2-4) and on a subsample of consecutive two-year panels of firms. ${ }^{14}$ The unbalanced panels sample thus contains firms that are in the data set in year $t$ and $t+1$, but not firms present in just one of the years, for any pair $t$ and $t+1$.

With the full sample, workers who continue to be employed in firms that drop out of the sample, due to, e.g., falling below the cut-off point or failing to report the data, are erroneously recorded as separating from the job. (Analogous errors are committed with respect to job accessions.) Our analysis deals with unskilled workers, but workers exiting to or entering from skilled occupations within the industry are recorded as being still employed and not newly hired, respectively. With the panels sample, workers in firms exiting or entering, in response to changing minimum wages, as well as workers in firms changing ownership over the two-year period are not accounted for. Running

\footnotetext{
${ }^{14}$ Restricting the panel to firms present in the data set over the whole estimation period would result in a substantial loss of observations.
} 
the same regressions on the two samples will reveal the sensitiveness of the results to these different characteristics.

Table 5. Estimated binomial logit models: Real minimum wage increases, 1979-91. Dependent variable: Probability not employed in the next period.

\begin{tabular}{|c|c|c|c|c|}
\hline \multirow[t]{2}{*}{ Variable } & \multicolumn{2}{|c|}{ Full sample } & \multicolumn{2}{|c|}{$\begin{array}{c}\text { Two-year } \\
\text { panels of firms }\end{array}$} \\
\hline & Coefficient & Elasticity & Coefficient & Elasticity \\
\hline Below (B) & $\begin{array}{l}5.256 \\
(0.743)\end{array}$ & 1.709 & $\begin{array}{c}6.151 \\
(0.825)\end{array}$ & 2.087 \\
\hline Treatment $(\mathrm{T})$ & $\begin{array}{c}3.953 \\
(0.441)\end{array}$ & 1.332 & $\begin{array}{c}3.795 \\
(0.486)\end{array}$ & 1.370 \\
\hline Control (C) & $\begin{array}{c}2.138 \\
(0.422)\end{array}$ & 0.756 & $\begin{array}{c}2.088 \\
(0.465)\end{array}$ & 0.787 \\
\hline T-C (elasticities) & & 0.576 & & 0.583 \\
\hline Test for equality, $T=C, \chi^{2}$ & & $\begin{array}{c}18.99 \\
{[0.0001]}\end{array}$ & & $\begin{array}{c}13.76 \\
{[0.0002]}\end{array}$ \\
\hline No. obs. & 83,302 & & 70,446 & \\
\hline-2 log likelihood & 101,768 & & 85,544 & \\
\hline Percent concordant & 66.8 & & 69.4 & \\
\hline
\end{tabular}

Notes: The regression models include the real hourly wage, a dummy for gender, age, age squared, 3 job tenure dummies, 3 occupation dummies, a dummy for permanent contract, number of employees, number of employees squared, 7 year dummies and 20 region dummies. The reference category for the variables in the table is High. "Percent concordant" refers to the association of predicted probabilities and observed responses. Standard errors in parentheses, $p$-values in brackets.

Table 5 shows the regression results for minimum wage increases over the period 1979-91. All individuals have been aggregated into the four groups below, treatment, control and high (which is the reference category). The variables $B$, $T$ and $C$ refer to the corresponding expressions in (1) and (2) for each group, depending on whether the sample contains increasing or decreasing minimum wages. The elasticities have been computed with respect to the minimum wage level, for comparability with other studies, and have been evaluated at the means of all variables, except $B, T$ and $C$ where the dummies in (1) and (2) in- 
dicating the relevant group have been set to unity (and the other dummies to zero). ${ }^{15}$

According to the results for the full sample, an increase in real minimum wages for $T$ by 1 percent increases job separations by 1.332 percent more than in the "high" group. The corresponding effect for $C$ is 0.756 . The difference in elasticities, $T-C$, can be interpreted as a treatment effect. It is significantly different from zero and amounts to 0.576 . In the presence of wage spillover to the control group, the difference should represent a lower bound of the treatment effect. ${ }^{16}$ The rightmost part of Table 5 presents the estimations for the panels sample, the results of which do not differ much from those of the full sample.

The estimations for the sample with decreasing minimum wages 1981-91 are displayed in Table 6. For the treatment group in the full sample, the elasticity is -0.610 . The increase in job accessions is thus larger than in the reference category. The difference in elasticities is 0.843 . The results for the panels sample differ somewhat regarding the elasticities for $T$ and $C$, but the difference is close to that of the full sample. Comparing the results to those of the previous table, the treatment effects $T-C$ are apparently somewhat larger for decreasing than for increasing minimum wages. To the extent that employment protection legislation makes it is easier for employers to adjust hiring than firing practices in response to changing minimum wages, this result is not unexpected.

\footnotetext{
${ }^{15}$ For, e.g., $T$, define $\Lambda(T)=\exp (\mathrm{T}) /(1+\exp (\mathrm{T}))$, where $\exp (\mathrm{T})=\mathrm{a}+\mathrm{b}^{\prime} \mathrm{z}+\mathrm{c} \Delta \mathrm{w}^{\min }, z$ is a vector of the explanatory variables (except $B, C$ and $T$ ), $c$ is the parameter for $T$ and $\Delta w^{\min }$ is the minimum wage change, i.e., the expression within brackets in (1) and (2). The elasticity for $T$ with respect to the minimum wage change is $c(1-\Lambda(T)) \Delta w^{\text {min }}$, while the elasticity with respect to the minimum wage level is $\mathrm{c}(1-\Lambda(\mathrm{T}))$.

${ }^{16}$ Assume that all of the measured effect for the control group is attributable to wage spillover, and the "real" elasticity $C$ should be set to zero. In this extreme case, the treatment effect $T-C$ amounts to 1.332 .
} 
Table 6. Estimated binomial logit models: Real minimum wage decreases, 1981-91. Dependent variable: Probability not employed in the previous period.

\begin{tabular}{|c|c|c|c|c|}
\hline \multirow[t]{2}{*}{ Variable } & \multicolumn{2}{|c|}{ Full sample } & \multicolumn{2}{|c|}{$\begin{array}{c}\text { Two-year } \\
\text { panels of firms }\end{array}$} \\
\hline & Coefficient & Elasticity & Coefficient & Elasticity \\
\hline Below (B) & $\begin{array}{l}-4.900 \\
(0.776)\end{array}$ & -1.166 & $\begin{array}{l}-5.441 \\
(0.830)\end{array}$ & -1.313 \\
\hline Treatment $(\mathrm{T})$ & $\begin{array}{l}-2.294 \\
(0.447)\end{array}$ & -0.610 & $\begin{array}{l}-3.349 \\
(0.478)\end{array}$ & -0.882 \\
\hline Control (C) & $\begin{array}{c}0.778 \\
(0.452)\end{array}$ & 0.234 & $\begin{array}{l}-0.138 \\
(0.480)\end{array}$ & -0.041 \\
\hline T-C (elasticities) & & -0.843 & & -0.841 \\
\hline Test for equality, $\mathrm{T}=\mathrm{C}, \chi^{2}$ & & $\begin{array}{c}65.46 \\
{[0.0001]}\end{array}$ & & $\begin{array}{c}62.77 \\
{[0.0001]}\end{array}$ \\
\hline No. obs. & 56,254 & & 49,363 & \\
\hline-2 log likelihood & 62,717 & & 54,685 & \\
\hline Percent concordant & 68.3 & & 69.4 & \\
\hline
\end{tabular}

Notes: See notes to Table 5.

The estimations for the post-1992 period were done for two samples, observations with individuals aged $18-19$ years and $20-65$ years, respectively. This is due to the fact that information on job tenure is not available regarding the former group. The results for increasing minimum wages during the 1993-98 are shown in Table 7 and differ somewhat from those of the previous period. The upper panel, which considers the older age group, reveals that the results for the treatment effects $T-C$ are sensitive to specification. In the full sample, the effect $T-C$ is 0.362 and insignificant (at the 5 per cent level), while the panels sample displays a larger and significant effect (1.004). The lower panel of Table 7 shows that, for teenagers, the elasticity for the treatment group is lower than for the control group, but the difference is not significant. Thus we are not able to establish that minimum wage increases have affected the employment 
of teenagers. It is possible that the large decrease in minimum wages for teenagers that occurred in 1993 caused subsequent increases to have little effect. ${ }^{17}$

Table 7. Estimated binomial logit models: Real minimum wage increases, 1993-98. Dependent variable: Probability not employed in the next period.

a. Workers aged 20-65.

\begin{tabular}{lcccc}
\hline Variable & \multicolumn{2}{c}{ Full sample } & \multicolumn{2}{c}{$\begin{array}{c}\text { Two-year } \\
\text { panels of firms }\end{array}$} \\
\hline Coefficient & Elasticity & Coefficient & Elasticity \\
\hline & 1.944 & 0.817 & 2.442 & 1.206 \\
& $(0.920)$ & & $(0.999)$ & \\
Treatment (T) & 2.383 & 0.992 & 2.530 & 1.247 \\
& $(0.501)$ & & $(0.547)$ & \\
Control (C) & 1.482 & 0.630 & 0.473 & 0.243 \\
& $(0.569)$ & & $(0.628)$ & \\
T-C (elasticities) & & & & 1.004 \\
Test for equality, T=C, $\chi^{2}$ & & 0.362 & & 12.25 \\
& & 2.82 & $0.0005]$ \\
No. obs. & & {$[0.0932]$} & & \\
-2 log likelihood & 56,915 & & & \\
Percent concordant & 72,366 & & 55,236 & \\
\hline
\end{tabular}

\footnotetext{
${ }^{17}$ The estimations do not take into account potential effects of the policy change in 1993, when the minimum wages for teenagers were decreased substantially. A major school reform, initiated in 1992 and fully implemented by 1995-96, coincides with the period when the effects of the decrease in minimum wages should be expected. The length of education was extended from two to three years for vocational fields of study in high schools. The reform implied a length of education of three years for all high-school students. This development is reflected in a large increase in job accession rates for eighteen-year-olds after 1993, since very few seventeen-year-olds have been employed. From 1995, every 18-year-old in the data set is newly hired. The simultaneous introduction of lower minimum wages for teenagers and the extended schooling period makes it difficult to disentangle the effects from minimum wages on accession rates.
} 
b (cont.). Workers aged 18-19.

\begin{tabular}{lcccc}
\hline Variable & \multicolumn{2}{c}{ Full sample } & \multicolumn{2}{c}{$\begin{array}{c}\text { Two-year } \\
\text { panels of firms }\end{array}$} \\
\hline & Coefficient & Elasticity & Coefficient & Elasticity \\
\hline Below (B) & 0.520 & 0.150 & 1.958 & 0.669 \\
& $(1.219)$ & & $(1.316)$ & \\
Treatment (T) & 0.514 & 0.148 & 0.479 & 0.178 \\
& $(0.501)$ & & $(0.760)$ & \\
Control (C) & 1.051 & 0.292 & 0.812 & 0.296 \\
& $(0.865)$ & & $(0.935)$ & \\
T-C (elasticities) & & & & -0.118 \\
Test for equality, T=C, $\chi^{2}$ & & -0.144 & & 0.16 \\
& & 0.48 & & \\
& & {$[0.4868]$} & & \\
No. obs. & 11,286 & & 8,128 & \\
-2 log likelihood & 13,116 & & 10,611 & \\
Percent concordant & 64.5 & & 56.9 & \\
\hline
\end{tabular}

Notes: The regression models include the real hourly wage, a dummy for gender, number of employees, number of employees squared, 5 year dummies and 20 region dummies. Table 7.a also includes age, age squared and 3 job tenure dummies. Table 7.b also includes a dummy for 19year-olds. See also notes to Table 5 .

The results presented so far suggest that - except for teenagers during 1993-98 - minimum wage increases and decreases contribute significantly to job separations and accessions, respectively. The effects are not dramatic, but of nonnegligible magnitude. Our results tend to lie between the small equivalent elasticities found by Abowd et al. (2000b, Tables 1-4) for U.S. workers and their substantially larger effects for French workers.

In the remainder of this section, we intend to examine whether the results of Tables 5 and 6 survive when subjected to various tests for robustness (for the period 1979-92 only). Since endogeneity of the minimum wages cannot be ruled out entirely, the following exercise, along the lines of Askildsen et al. (2000), was performed. In the first step, minimum wages for each worker were predicted in an OLS regression with lagged minimum wages, occupation, job tenure, region dummies and year dummies. Then the sample was, as before, divided in the four groups depending on the location in the wage distribution and the binomial logit regressions were rerun. 
Another robustness test is motivated by a concern that employers adjust employment in response to changes in the minimum wages only with a lag. Since minimum wages are sometimes changed shortly before the month of September, which is the reporting month for employment, it is conceivable that employers do not react to the change in the same year. In order to investigate this possibility, increases in minimum wages are defined by the criterion

$$
w_{t-1}^{\min }<w_{t}^{\min }
$$

while decreases are defined by

$$
w_{t-1}^{\min }<w_{t-2}^{\min } .
$$

Apart from the lagged changes in the minimum wages, the analysis is performed as before.

The sensitivity of the results to increasing the wage interval for the control group was also checked. Two intervals were tested, 10 and 15 percent. In addition, various measures of the minimum wage were considered. Firstly, the sensitivity of the estimates to excluding the value added tax from the price deflator was checked. ${ }^{18}$ Secondly, payroll taxes were added. It can be argued that an appropriate measure of the minimum wage as a cost to the employer, relevant when separations are layoffs, should include payroll taxes. The payroll tax rate is independent of the wage, so the inclusion of the tax does not affect relative wages. Thirdly, the economy-wide CPI, used in previous studies on gross flows, was tried instead of the industry-specific as the deflator for the minimum wage variables. ${ }^{19}$ This is the proper wage measure, to the extent that separations mainly are quits. Using alternative measures of the minimum wage may alter the direction and size of the real minimum wage changes and the size of the groups used in the analysis.

\footnotetext{
${ }^{18}$ In 1990, the value added tax applying to hotels and restaurants was raised from 12.87 to 25 percent. It was reduced to 18 percent in 1992. After 1993, differential rates have been implemented for hotels ( 12 percent) and restaurants ( 25 percent, take-away meals 12 percent).

${ }^{19}$ According to conventional models, increases in the minimum should be translated into price increases (proportional to the affected workers' share of total factor costs).
} 
Table 8. Robustness tests of treatment effects in Tables 5 and 6. Differences in elasticities (T-C). Real minimum wage increases, 1979-91, and decreases, 1981-91. Various model specifications.

a. Various wage measures and wage intervals.

\begin{tabular}{|c|c|c|c|c|}
\hline \multirow[b]{2}{*}{ Model specification } & \multicolumn{2}{|c|}{ Full sample } & \multicolumn{2}{|c|}{$\begin{array}{c}\text { Two-year } \\
\text { panels of firms }\end{array}$} \\
\hline & $\begin{array}{c}\text { Increases } \\
\mathrm{T}-\mathrm{C}\end{array}$ & $\begin{array}{c}\text { Decreases } \\
\text { T-C }\end{array}$ & $\begin{array}{c}\text { Increases } \\
\mathrm{T}-\mathrm{C}\end{array}$ & $\begin{array}{c}\text { Decreases } \\
\mathrm{T}-\mathrm{C}\end{array}$ \\
\hline Predicted minimum wages & $\begin{array}{c}0.619 \\
{[0.0002]} \\
\{69,745 \text { obs. }\}\end{array}$ & $\begin{array}{c}-0.906 \\
{[0.0001]} \\
\{55,988 \text { obs. }\}\end{array}$ & $\begin{array}{c}0.575 \\
{[0.0037]} \\
\{58,917 \text { obs. }\}\end{array}$ & $\begin{array}{c}-0.906 \\
{[0.0001]} \\
\{49,164 \text { obs. }\}\end{array}$ \\
\hline Lagged minimum wages & $\begin{array}{c}-0.635 \\
{[0.0313]} \\
\{51,068 \text { obs. }\}\end{array}$ & $\begin{array}{c}-1.106 \\
{[0.0001]} \\
\{71,749 \text { obs. }\}\end{array}$ & $\begin{array}{c}0.253 \\
{[0.4926]} \\
\{42,805 \text { obs. }\}\end{array}$ & $\begin{array}{c}-1.176 \\
{[0.0001]} \\
\{61,249 \text { obs. }\}\end{array}$ \\
\hline $\begin{array}{l}\text { Wage interval } 10 \% \\
\text { (instead of } 5 \% \text { ) }\end{array}$ & $\begin{array}{c}0.862 \\
{[0.0001]} \\
\{83,302 \text { obs. }\}\end{array}$ & $\begin{array}{c}-0.928 \\
{[0.0001]} \\
\{56,254 \text { obs. }\}\end{array}$ & $\begin{array}{c}0.879 \\
{[0.0001]} \\
\{70,446 \text { obs. }\}\end{array}$ & $\begin{array}{c}-0.987 \\
{[0.0001]} \\
\{49,363 \text { obs. }\}\end{array}$ \\
\hline $\begin{array}{l}\text { Wage interval } 15 \% \\
\text { (instead of } 5 \% \text { ) }\end{array}$ & $\begin{array}{c}0.979 \\
{[0.0001]} \\
\{83,302 \text { obs. }\}\end{array}$ & $\begin{array}{c}-0.915 \\
{[0.0001]} \\
\{56,254 \text { obs. }\}\end{array}$ & $\begin{array}{c}0.996 \\
{[0.0001]} \\
\{70,446 \text { obs. }\}\end{array}$ & $\begin{array}{c}-1.029 \\
{[0.0001]} \\
\{49,363 \text { obs. }\}\end{array}$ \\
\hline Excluding value added tax & $\begin{array}{c}0.295 \\
{[0.0070]} \\
\{79,996 \text { obs. }\}\end{array}$ & $\begin{array}{c}-0.350 \\
{[0.0002]} \\
\{58,051 \text { obs. }\}\end{array}$ & $\begin{array}{c}0.378 \\
{[0.0043]} \\
\{67,479 \text { obs. }\}\end{array}$ & $\begin{array}{c}-0.484 \\
{[0.0001]} \\
\{51,023 \text { obs. }\}\end{array}$ \\
\hline Including payroll taxes & $\begin{array}{c}0.603 \\
{[0.0001]} \\
\{83,446 \text { obs. }\}\end{array}$ & $\begin{array}{c}-0.831 \\
{[0.0001]} \\
\{55,988 \text { obs. }\}\end{array}$ & $\begin{array}{c}0.739 \\
{[0.0001]} \\
\{70,573 \text { obs. }\}\end{array}$ & $\begin{array}{c}-0.801 \\
{[0.0001]} \\
\{49,164 \text { obs. }\}\end{array}$ \\
\hline $\begin{array}{l}\text { General CPI (instead of } \\
\text { industry-specific) }\end{array}$ & $\begin{array}{c}0.919 \\
{[0.0001]} \\
\{81,314 \text { obs. }\}\end{array}$ & $\begin{array}{c}-2.055 \\
{[0.0001]} \\
\{45,806 \text { obs. }\}\end{array}$ & $\begin{array}{c}0.970 \\
{[0.0001]} \\
\{68,125 \text { obs. }\}\end{array}$ & $\begin{array}{c}-1.891 \\
{[0.0001]} \\
\{40,004 \text { obs. }\}\end{array}$ \\
\hline
\end{tabular}


b (cont.). Various subgroups.

\begin{tabular}{|c|c|c|c|c|}
\hline \multirow[b]{2}{*}{ Model specification } & \multicolumn{2}{|c|}{ Full sample } & \multicolumn{2}{|c|}{$\begin{array}{c}\text { Two-year } \\
\text { panels of firms }\end{array}$} \\
\hline & $\begin{array}{c}\text { Increases } \\
\mathrm{T}-\mathrm{C}\end{array}$ & $\begin{array}{c}\text { Decreases } \\
\text { T-C }\end{array}$ & $\begin{array}{c}\text { Increases } \\
\mathrm{T}-\mathrm{C}\end{array}$ & $\begin{array}{c}\text { Decreases } \\
\mathrm{T}-\mathrm{C}\end{array}$ \\
\hline$\geq 70$ employees & $\begin{array}{c}0.761 \\
{[0.0001]} \\
\{51,688 \text { obs. }\}\end{array}$ & $\begin{array}{c}-0.958 \\
{[0.0001]} \\
\{37,301 \text { obs. }\}\end{array}$ & $\begin{array}{c}0.598 \\
{[0.0010]} \\
\{45,872 \text { obs. }\}\end{array}$ & $\begin{array}{c}-0.940 \\
{[0.0001]} \\
\{34,498 \text { obs. }\}\end{array}$ \\
\hline One large chain & $\begin{array}{c}1.363 \\
{[0.0070]} \\
\{8,757 \text { obs. }\}\end{array}$ & $\begin{array}{c}-1.498 \\
{[0.0001]} \\
\{6,471 \text { obs. }\}\end{array}$ & & \\
\hline Teenagers & $\begin{array}{c}0.765 \\
{[0.0021]} \\
\{17,806 \text { obs. }\}\end{array}$ & $\begin{array}{c}-0.551 \\
{[0.0137]} \\
\{15,327 \text { obs. }\}\end{array}$ & $\begin{array}{c}0.800 \\
{[0.0039]} \\
\{14,999 \text { obs. }\}\end{array}$ & $\begin{array}{c}-0.453 \\
{[0.0514]} \\
\{13,266 \text { obs. }\}\end{array}$ \\
\hline Job tenure $<1$ year & $\begin{array}{c}0.526 \\
{[0.0003]} \\
\{49,632 \text { obs. }\}\end{array}$ & $\begin{array}{c}-0.689 \\
{[0.0001]} \\
\{46,246 \text { obs. }\}\end{array}$ & $\begin{array}{c}0.399 \\
{[0.0120]} \\
\{41,945 \text { obs. }\}\end{array}$ & $\begin{array}{c}-0.634 \\
{[0.0001]} \\
\{40,696 \text { obs. }\}\end{array}$ \\
\hline Fixed-term contract & $\begin{array}{c}0.539 \\
{[0.0169]} \\
\{29,544 \text { obs. }\}\end{array}$ & $\begin{array}{c}-0.545 \\
{[0.0001]} \\
\{28,311 \text { obs. }\}\end{array}$ & $\begin{array}{c}0.317 \\
{[0.0995]} \\
\{24,915 \text { obs. }\}\end{array}$ & $\begin{array}{c}-0.492 \\
{[0.0001]} \\
\{25,543 \text { obs. }\}\end{array}$ \\
\hline Forest counties & $\begin{array}{c}0.755 \\
{[0.0223]} \\
\{13,499 \text { obs. }\}\end{array}$ & $\begin{array}{c}-1.011 \\
{[0.0001]} \\
\{9,022 \text { obs. }\}\end{array}$ & $\begin{array}{c}0.507 \\
{[0.2551]} \\
\{11,158 \text { obs. }\}\end{array}$ & $\begin{array}{c}-0.805 \\
{[0.0048]} \\
\{7,834 \text { obs. }\}\end{array}$ \\
\hline
\end{tabular}

Notes: Separate estimations were performed in each case. The sample periods for the estimations with (i) predicted minimum wages is 1980-91 (increases); (ii) lagged minimum wages is 1980 91 (increases) and 1982-92 (decreases); and (iii) excluding value added tax is 1980-91 (decreases). P-values within square brackets. See also notes to Table 5.

Another potential problem is that the occurrence of underground work produces measurement errors in the data, obscuring the true relationship between minimum wages and employment. With many such workers, job separations would tend to be overestimated in the treatment group when minimum wages are increasing, to the extent that unofficial workers remain employed or whitesector workers shift to the black market. Similarly, new hirings in the treatment group when minimum wages are decreasing would be overestimated. In order to test for the robustness of our results to underground activity, the strategy is to run the regressions on a subsample of large firms (with at least 70 employ- 
ees). ${ }^{20}$ Possible biases stemming from firm heterogeneity is eliminated by reducing the sample to a single, large firm (a chain which is present in the sample during the whole estimation period). This regression also serves as another test for effects from underground work.

It can be noted that an underlying assumption in Tables 5-7 is that the difference between the treatment and control groups $(T-C)$ is the same for all workers. This may obviously be unrealistic in many cases. Therefore, additional checks for robustness were performed on subgroups whose employment can be expected to be particularly sensitive to changing minimum wages teenagers, workers with job tenure less than one year, workers on a fixed-term contract and workers in the unemployment-ridden forest counties in the northern part of Sweden. The results of the various robustness tests are summarised in Table 8.

According to the estimations, which replicate the format of Tables 5-6, but are not reported in full, the treatment effect $T-C$ is in most cases rather close to the previously reported results. The estimations are confined to the period 1979-91. The effects are largest when general price inflation is used as the wage deflator and large chain. In particular, the effect $T$ - $C$ is larger (around -2.0) for decreasing wages using the general CPI. ${ }^{21}$ In only one instance, where minimum wages were lagged, does the difference come out with an unexpected (negative) sign for minimum wage increases in the full sample. The corresponding difference is, however, positive (but insignificant) in the panels sample. Consistently smaller treatment effects, although still mostly significant, are found in the estimations where the value added tax is excluded and in the estimations for workers on fixed-term contracts. It can be noted that the treatment effects for teenagers are significant and much larger than in Table 7.b. This reinforces the suspicion that the reduction of minimum wages for teenagers in 1993 contributed to the small effects during the later period. The overall conclusion from Table 8 is that that the employment effects of minimum wage changes found in Tables 5 and 6 do survive when subjected to various robustness tests.

\footnotetext{
${ }^{20}$ An additional reason to consider the subsample of large firms is that in very small establishments ( $1-5$ employees) the distinction between family members and employees is less clear and this may also bias the results.

${ }^{21}$ Since the general price inflation has been lower than in the industry, there are fewer observations with decreasing wages.
} 
An advantage with the diversified minimum wage structure is that it is possible to identify workers within the same overlapping wage intervals as workers affected by increasing or decreasing minimum wages, but who are not affected according to the assumptions in the previous estimations. These workers have been subjected to "pseudo-treatment" (with associated elasticity $P T$ ) and should not be expected to differ in behaviour from their respective "pseudocontrol" groups (with associated elasticity $P C$ ) with respect to the changing minimum wages affecting the ordinary treatment groups. The double difference in elasticities, $T-C-(P T-P C)$, is an alternative measure of the treatment effect. This measure takes into account that $T-C$ may not only reflect responses to changing minimum wages but also unobserved and differences between the groups - differences which, however, are assumed to be captured by $P T-P C$, to the extent that the differences are common for groups of workers within the same wage intervals.

It is possible to consider the pseudo-experiment only for workers with lower minimum wages than those affected by a particular change in minimum wages. As a final exercise, we thus examine the treatment effects for level I restaurant assistants by also looking at the pseudo-treatment and pseudo-control groups for the lower-paid level II restaurant assistants. Similarly, workers in the Greater Stockholm area are compared to workers outside Greater Stockholm and workers with long tenure are compared to workers with short tenure. (See Appendix for full details on the sample partition with pseudo-experiments.)

The results are summarised in Table 9, which displays the simple-difference treatment effects $T-C$ and pseudo-treatment effects $P T-P C$ as well as the double-difference treatment effects $T-C-(P T-P C)$. Again, the format closely follows the regressions in Tables 5 and 6 , as far as estimation periods and included variables are concerned. The upper panel considers increasing minimum wages. The simple-difference treatment effects are quite large, ranging between 1.4 and 2.9, but it should be noted that the results are not directly comparable to those in Tables 5 and 8 , since the (overlapping) wage intervals for the treatment and pseudo-treatment groups by construction are narrower in Table 9. The differing results may also reflect parameter heterogeneity in the pooled estimations of Tables 5 and 8 .

The pseudo-treatment effects are in most cases non-negligible (albeit sometimes imprecisely estimated), which suggests that the simple-difference treatment effects do not entirely control for unobserved individual heterogeneity. The double-difference treatment effects are, in general, at least as large as the 
simple differences in Tables 5 and 8. Only in one instance, where workers with at least three years' tenure and workers with at least one year's tenure were chosen as comparison groups (in the panels sample), does the difference come out insignificantly. ${ }^{22}$

Table 9. Estimations with various pseudo-experiments. Simpledifference treatment effects (T-C), pseudo-treatment effects (PT-PC) and double-difference treatment effects (T-C-(PT-PC)). Differences in elasticities.

a. Real minimum wage increases.

\begin{tabular}{|c|c|c|c|c|c|c|}
\hline \multirow[b]{2}{*}{ Model specification } & \multicolumn{3}{|c|}{ Full sample } & \multicolumn{3}{|c|}{$\begin{array}{l}\text { Two-year } \\
\text { panels of firms }\end{array}$} \\
\hline & $\mathrm{T}-\mathrm{C}$ & PT-PC & $\begin{array}{c}\text { T-C- } \\
\text { (PT-PC) }\end{array}$ & $\mathrm{T}-\mathrm{C}$ & PT-PC & $\begin{array}{c}\text { T-C- } \\
\text { (PT-PC) }\end{array}$ \\
\hline Two occupations & $\begin{array}{c}2.938 \\
{[0.0041]}\end{array}$ & $\begin{array}{c}0.569 \\
{[0.0410]} \\
\{20,355 \text { obs }\end{array}$ & $\begin{array}{c}2.369 \\
{[0.0176]}\end{array}$ & $\begin{array}{c}3.227 \\
{[0.0133]}\end{array}$ & $\begin{array}{c}0.459 \\
{[0.1466]} \\
17,172 \mathrm{obs}\end{array}$ & $\begin{array}{c}2.768 \\
{[0.0333]}\end{array}$ \\
\hline Two regions & $\begin{array}{c}1.746 \\
{[0.0018]}\end{array}$ & $\begin{array}{c}0.369 \\
{[0.4004]} \\
\{10,405 \text { obs }\end{array}$ & $\begin{array}{c}1.376 \\
{[0.0558]}\end{array}$ & $\begin{array}{c}1.476 \\
{[0.0124]}\end{array}$ & $\begin{array}{c}0.017 \\
{[0.9779]} \\
\{9,242 \text { obs. }\end{array}$ & $\begin{array}{c}1.459 \\
{[0.0498]}\end{array}$ \\
\hline Two tenure groups & $\begin{array}{c}1.383 \\
{[0.0001]}\end{array}$ & $\begin{array}{c}0.700 \\
{[0.0663]} \\
\{25,554 \mathrm{obs}\end{array}$ & $\begin{array}{c}0.683 \\
{[0.0455]}\end{array}$ & $\begin{array}{c}1.327 \\
{[0.0068]}\end{array}$ & $\begin{array}{c}1.367 \\
{[0.0005]} \\
21,974 \mathrm{obs}\end{array}$ & $\begin{array}{c}-0.040 \\
{[0.9322]}\end{array}$ \\
\hline
\end{tabular}

\footnotetext{
${ }^{22}$ There were too few observations in the treatment and pseudo-treatment groups for workers with at least two years' tenure.
} 
b (cont.). Real minimum wage decreases.

\begin{tabular}{|c|c|c|c|c|c|c|}
\hline \multirow[b]{2}{*}{ Model specification } & \multicolumn{3}{|c|}{ Full sample } & \multicolumn{3}{|c|}{$\begin{array}{c}\text { Two-year } \\
\text { panels of firms }\end{array}$} \\
\hline & $\mathrm{T}-\mathrm{C}$ & PT-PC & $\begin{array}{c}\text { T-C- } \\
\text { (PT-PC) }\end{array}$ & $\mathrm{T}-\mathrm{C}$ & PT-PC & $\begin{array}{c}\text { T-C- } \\
\text { (PT-PC) }\end{array}$ \\
\hline Two occupations & $\begin{array}{c}-1.599 \\
{[0.0237]}\end{array}$ & $\begin{array}{c}0.005 \\
{[0.9850]} \\
\{11,742 \text { obs }\end{array}$ & $\begin{array}{c}-1.604 \\
{[0.0277]}\end{array}$ & $\begin{array}{c}-1.701 \\
{[0.0014]}\end{array}$ & $\begin{array}{c}-0.093 \\
{[0.7494]} \\
10,310 \mathrm{ob}\end{array}$ & $\begin{array}{c}-1.609 \\
{[0.0025]}\end{array}$ \\
\hline Two regions & $\begin{array}{c}0.318 \\
{[0.3553]}\end{array}$ & $\begin{array}{c}-0.867 \\
{[0.0295]} \\
\{12,184 \mathrm{ob}\end{array}$ & $\begin{array}{c}1.185 \\
{[0.0328]}\end{array}$ & $\begin{array}{c}-0.442 \\
{[0.1065]}\end{array}$ & $\begin{array}{c}-0.934 \\
{[0.0372]} \\
11,000 \mathrm{ob}\end{array}$ & $\begin{array}{c}0.492 \\
{[0.9581]}\end{array}$ \\
\hline
\end{tabular}

Notes: Separate estimations were performed in each case. The two occupations are restaurant assistants, level I (treatment effect) and level II (pseudo-treatment effect), respectively. The two regions are Greater Stockholm (treatment effect) and outside Greater Stockholm (pseudo-treatment effect). The two tenure groups are workers with at least three years' tenure (treatment group) and workers with at least one year's tenure (pseudo-treatment group). The sample periods for the estimations with (i) the two occupations are 1979-91(increases) and 1981-91 (decreases); (ii) the two regions 1981-84 (increases and decreases); and (iii) the two tenure groups 1979-91 (increases). The number of observations in the treatment and pseudo-treatment groups (in the full sample) are for (i) above, 247 and 4,503, respectively (increases), 299 and 3,392 (decreases); for (ii), 900 and 990 (increases), 877 and 1,383 (decreases); and for (iii) 3,565 and 4,395 (increases). See also notes to Table 5 and 8 .

The lower panel of Table 9 shows the results for decreasing minimum wages. For the two occupations the effects are of similar (absolute) magnitude as for increasing minimum wages. In the estimations with two regions, the double differences come out with unexpected signs (but only significantly so in the full sample). The evidence in support of strong employment effects is thus more mixed when pseudo-experiments with decreasing minimum wages are considered.

\section{Conclusions}

Using data from hotels and restaurants over the period 1979-99, this study finds that changes in minimum wages in general are associated with nonnegligible employment effects. Teenagers during the period 1993-98 do not seem to be affected, however. The evidence in support of employment effects tends to be robust across various model specifications. In addition, pseudoexperiments arising from the diversified minimum wage structure have been examined. Since the pseudo-treatment effects in most cases turn out to be non- 
zero, it seems appropriate to consider pseudo-experiments in the estimations. These exercises indicate less clear-cut results for decreasing minimum wages, however, since the employment effects are quite sensitive to the choice of comparison groups.

Our results differ from previous studies by, e.g., Card \& Krueger (1994, $1995)$ on U.S. fast-food restaurants, which failed to establish adverse employment effects from minimum wages. A possible explanation may be that the minimum wage bite in Sweden tends to be larger than in the U.S. (and the U.K.) in general (Dolado et al., 1996, Table 1). In Swedish hotels and restaurants, the minimum wage bite among unskilled workers above the age of 20 is around 85-90 percent of prime-age workers' wages in the same industry. The small employment effects found during the period with substantially reduced minimum wages for teenagers (1993-98) also suggest that the level of minimum wages may be important.

It should be cautioned that any remaining unobserved individual heterogeneity may bias the results, to the extent that it is correlated with variables indicating whether a worker is subject to treatment or not. The fact that few individuals are observed over two consecutive periods renders standard fixedeffects estimation in order to control for unobserved individual heterogeneity intractable.

There may be other forms of adjustment in the short run, not considered in this study, such as effects on work hours or the incidence of fixed-term contracts. In addition, the changes in the minimum wage structure that have occurred may have had repercussions on wage dispersion, both within the group of unskilled workers and between unskilled and skilled workers. 


\section{References}

Abowd, J M, F Kramarz, T Lemieux and D N Margolis (2000a), "Minimum wages and youth employment in France and the United States", in D Blanchflower and R Freeman (eds): Youth employment and joblessness in advanced countries, University of Chicago Press.

Abowd, J M, F Kramarz, D N Margolis and T Philippon (2000b), "The tail of two countries: Minimum wages and unemployment in France and the United States", Working paper no. 203, IZA, Bonn.

Askildsen, J E, K E Lommerud, O A Nilsen and K G Salvanes (2000), "Union bargained minimum wages: Are there any employment effects?", mimeo, University of Bergen, Norway.

Baltagi, B H (1995), Econometric analysis of panel data, Wiley.

Card, D and A Krueger (1994), "Minimum Wages and Employment: A Case Study of the Fast Food Industry in New Jersey and Pennsylvania", American Economic Review, 84, 772-793.

Card, D and A Krueger (1995), Myth and measurement: The new evidence of the minimum wage, Princeton, NJ: Princeton University Press.

Currie J and B C Fallick (1996), "The minimum wage and the employment of youth: Evidence from the NLSY", Journal of Human Resources, 31, 404-428.

Dickens, R, S Machin, and A Manning (1999), "The effects of minimum wages on employment: Theory and evidence from Britain", Journal of Labor Economics, 17, 1-22.

Dolado, J, F Kramarz, S Machin, A Manning, D Margolis and C Teulings (1996), "The economic impact of minimum wages in Europe", Economic Policy, 317-357.

Edin, P A and B Holmlund (1994), Arbetslösheten och arbetsmarknadens funktionssätt, Bilaga 8 till 1994 års Långtidsutredning, Fritzes, Stockholm.

Greene, W H (1993), Econometric analysis, second edition, Macmillan.

Machin, S and A Manning (1994), "The effects of minimum wages on wage dispersion and employment: Evidence from the U.K. Wages Councils", Industrial and Labor Relations Review, 47, 319-329.

Neumark, D and W Wascher (1992), "Employment effects of minimum and subminimum wages: Panel data on state minimum wage laws", Industrial and Labor Relations Review, 46, 55-81. 
OECD (1998), Employment outlook. OECD, Paris.

Östros, T (1994), "Do minimum wages matter? The case of Swedish mining and manufacturing", in Holmlund, B (ed): Pay, Productivity, and Policy. Essays on Wage Behavior in Sweden. Trade Union Institute for Economic Research, Stockholm.

SHR (1996), Hotell- \& Restaurangfakta - 96, the Swedish Hotel and Restaurant Employers' Association, Stockholm.

SHR (1997), Verksamhetsberättelse 1997, the Swedish Hotel and Restaurant Employers' Association, Stockholm.

SHR (1998), SHRs Nyckeltalsundersökning 1998, the Swedish Hotel and Restaurant Employers' Association, Stockholm.

Zavodny, M (2000), "The effect of the minimum wage on employment and hours", Labour Economics, 7, 729-750. 


\section{Appendix: The sample partition with pseudo-experiments}

Assume the following minimum wage structure under an increasing minimum:

$$
\boldsymbol{w i n}_{h, t}<\boldsymbol{m i n}_{\boldsymbol{m}_{h, t+1}}, \boldsymbol{w}_{\ell, t}<\min _{\ell, t+1}, \boldsymbol{w i n}_{\ell, t+1}<\boldsymbol{w i n}_{h, t+1},
$$

where subscripts $h$ and $\ell$ indicate two groups of workers with different minimum wages (high and low, respectively) and $t$ denotes year. Given that the three conditions are fulfilled, the data set is divided into the following six groups:

$$
\begin{array}{ll}
\text { Below: } & w_{i, h, t}<\operatorname{Max}\left(w_{h, t}^{\min }, w_{\ell, t+1}^{\min }\right) \\
\text { Treatment: } & \operatorname{Max}\left(w_{h, t}^{\min }, w_{\ell, t+1}^{\min }\right) \leq w_{i, h, t}<w_{h, t+1}^{\min } \\
\text { Control: } & w_{h, t+1}^{\min } \leq w_{i, h, t}<w_{h, t+1}^{\min } x 1.05 \\
\text { High: } & w_{i, h, t} \geq w_{h, t+1}^{\min } \times 1.05 \\
\text { Pseudo-treatment: } & \operatorname{Max}\left(w_{h, t}^{\min }, w_{\ell, t+1}^{\min }\right) \leq w_{i, \ell, t}<w_{h, t+1}^{\min } \\
\text { Pseudo-control: } & w_{h, t+1}^{\min } \leq w_{i, \ell, t}<w_{h, t+1}^{\min } \times 1.05,
\end{array}
$$

where subscript $i$ indicates an individual worker. The treatment group in this case is the one with a higher minimum wage. The maximum function enters in the expression, because in year $t$ the minimum wage for group $h$ is allowed to be either lower or higher than for group $\ell$ in $t+1$. The highest wage of the two is used to define the lower bound of the wage interval for the treatment group. The purpose is to create a treatment group of type $h$ workers $(T)$ and a pseudotreatment $(P T)$ group of type $\ell$ workers within the same overlapping segment of wages, both with increasing minimum wages. 
Analogously, a control $(C)$ and a pseudo-control $(P C)$ group are constructed within the same interval of wages. Within the group with lower minimum wages $(\ell)$, no difference in job separation rates arising from increasing minimum wages is expected, hence the label "pseudo". Any difference is assumed not to be related to minimum wages. The hypothesis in this case is that the double difference $T-C-(P T-P C)$ captures the impact of increasing minimum wages on job separation rates in group $h$, purged from unobserved characteristics common with group $\ell$.

With decreasing minimum wages, assume the following structure:

$$
w_{h, t}^{\min }<w_{h, t-1}, w_{\ell, t}^{\min }<w_{\ell, t-1}, w_{\ell, t-1}^{\min }<w_{h, t-1} .
$$

The various groups are defined as below:

$$
\begin{array}{ll}
\text { Below: } & w_{i, h, t}<\operatorname{Max}\left(w_{h, t}^{\min }, w_{\ell, t-1}^{\min }\right) \\
\text { Treatment: } & \operatorname{Max}\left(w_{h, t}^{\min }, w_{\ell, t-1}^{\min }\right) \leq w_{i, h, t}<w_{h, t-1}^{\min } \\
\text { Control: } & w_{h, t-1}^{\min } \leq w_{i, h, t}<w_{h, t-1}^{\min } x 1.05 \\
\text { High: } & w_{i, h, t} \geq w_{h, t-1}^{\min } \times 1.05 \\
\text { Pseudo-treatment: } & \operatorname{Max}\left(w_{h, t}^{\min }, w_{\ell, t-1}^{\min }\right) \leq w_{i, \ell, t}<w_{h, t-1}^{\min } \\
\text { Pseudo-control: } & w_{h, t-1}^{\min } \leq w_{i, \ell, t}<w_{h, t-1}^{\min } x 1.05 .
\end{array}
$$

Again, the treatment group is the group with higher minimum wages. The assumption is that the double difference $T-C-(P T-P C)$ captures the impact of decreasing minimum wages on job accession rates in group $h$, controlling for unobserved characteristics common with group $\ell$. 